\title{
The Impact of Microbial Transglutaminase on the Quality and Antioxidant Activity of Camel-Milk Soft Cheese
}

\author{
Nagwa Hussein Ismail Abou-Soliman1, Sameh Awad², Mahmoud Ibrahim El-Sayed ${ }^{*}$ \\ ${ }^{1}$ Animal Breeding Department, Animal and Poultry Production Division, Desert Research Centre, Matariya, Cairo, Egypt \\ ${ }^{2}$ Department of Dairy Science and Technology, Faculty of Agriculture, Alexandria University, Alexandria, Egypt \\ ${ }^{3}$ Department of Dairy Technology Research, Food Technology Research Institute, Agricultural Research Center, Giza, Egypt \\ Email: ^mahmoud_im1981@yahoo.com, ^mahmoudibrahim_eg@yahoo.com
}

How to cite this paper: Abou-Soliman, N.H.I., Awad, S. and El-Sayed, M.I. (2020) The Impact of Microbial Transglutaminase on the Quality and Antioxidant Activity of Camel-Milk Soft Cheese. Food and Nutrition Sciences, 11, 153-171.

https://doi.org/10.4236/fns.2020.113012

Received: February 4, 2020

Accepted: March 2, 2020

Published: March 5, 2020

Copyright () 2020 by author(s) and Scientific Research Publishing Inc. This work is licensed under the Creative Commons Attribution International License (CC BY 4.0).

http://creativecommons.org/licenses/by/4.0/

\begin{abstract}
This study aimed at investigating the impact of adding microbial transglutaminase (MTGase) after rennet addition on some properties of fresh soft cheese made from camel milk. MTGase was added to milk at concentration of 80,100 and $120 \mathrm{U} / \mathrm{L}$ after 20 and $30 \mathrm{~min}$ of renneting. The chemical composition, yield, hardness, antioxidant activity and sensory properties of cheese were estimated. Enzymatic protein crosslinking was analyzed by SDS-PAGE. Results revealed that MTGase-treated cheeses were higher in moisture and lower in protein content compared to control. In addition, the concentration of MTGase and time of addition significantly $(P<0.05)$ impacted these parameters. Among treated cheeses, samples with $80 \mathrm{U}$ of MTGase and addition time of $20 \mathrm{~min}$ were the highest in total solids and protein content. Adding MTGase significantly $(P<0.05)$ increased the cheese yield, however, increased MTGase concentration at any time of addition did not improve it. The electrophoretic patterns of MTGase-cheese proteins showed a reduction in the intensity of caseins bands and the appearance of new protein fractions with high molecular weights. However, the changes in the intensity of the whey proteins bands were not sufficiently clear as caseins. The cheese hardness was significantly $(P<0.05)$ affected by adding MTGase. Cheese containing $80 \mathrm{U}$ of MTGase had the highest hardness value compared to control and other treated samples. The antioxidant activity of cheese was negatively influenced by adding the enzyme. The use of MTGase enhanced the mouthfeel, texture and overall acceptability of cheese. However, the effect of MTGase concentration and addition time was not significant $(P>0.05)$ on the sensory attributes. In conclusion, adding MTGase to milk at concentration of $80 \mathrm{U}$ after $20 \mathrm{~min}$ of renneting is recommended to improve the yield, textural and some sensory properties of fresh soft cheese made from camel milk.
\end{abstract}




\section{Keywords}

Camel Milk, Soft Cheese, Transglutaminase, Texture and Yield, Antioxidant Activity

\section{Introduction}

Camel milk plays an important role in nutrition, particularly in hot and dry zones, in which milk is consumed fresh or as fermented milk. Recently and in conjunction with the global trend of consuming functional foods, several studies have been carried out to emphasize the therapeutic and healthy role of camel milk for humans [1]. Nevertheless, camel milk is difficult to process into dairy products that are acceptable to consumers and can compete commercially due to the problems facing the manufacture of these products, particularly cheese.

Camel milk is characterized by its poor rennetability; it shows long rennet coagulation time [2]. Camel milk fails to form an actual curd structure, but just flakes that lack firmness are produced [3] as well as the cheese yield is low [4]. All of these problems are related to the nature of camel milk. Compared to cow milk, camel milk often has a lower content of dry matter, particularly casein [3]. It contains smaller fat globules [5]. Besides, the casein composition of camel milk is qualitatively and quantitatively different from that of cow milk. It contains a greater number of large micelles [3]. The cleavage site of chymosin in camel milk $\kappa$-casein $\left(\mathrm{Phe}^{97}-\mathrm{Il}^{98}\right)$ is different from that of cow milk $\left(\mathrm{Phe}^{105}-\mathrm{Met}^{106}\right)$ as reported by [6]. Additionally, the ratios of casein fractions to whole casein in camel milk can negatively impact the curd coagulation and firmness, as $\beta-, \alpha_{s 1}$ and $\kappa$-caseins constitute about $65 \%, 21 \%$ and $3.47 \%$, respectively of whole casein [6].

Several strategies have been reported to accelerate camel milk coagulation and to improve the cheese properties and yield, for instance, using ultrafiltration technique [7], fortifying camel milk with the milk of other ruminants [4] or using camel gastric enzymes instead of the commercial rennet [8]. Recently, camel chymosin (CHY-MAX ${ }^{\oplus}$ M), which introduced to the market since 2008, has shown good results for camel milk coagulation [9]. In addition, the utilization of microbial transglutaminase (MTGase) has been addressed to improve the properties of soft cheese [10].

MTGase isolated from Streptoverticillium mobaraense is an enzyme that catalyzes acyl-transfer reactions, which results in formation of new isopeptide bonds that can modify the structural and functional properties of proteins without any impact on the bioavailability of lysine residue [11]. MTGase is a useful tool for processing dairy products with new features due to the enzyme-induced reactions. There are a number of patents in this regard that are listed by [12]. MTGase has been approved by food industries, today almost cheese varieties are produced using this enzyme [13]. The benefits of using MTGase in cheese man- 
ufacture have been reviewed [12] [14]. Briefly, MTGase helps to enhance the yield, water-holding capacity, texture, rheology and sensory properties of cheese. In addition, this enzyme has nutritional, economic and environmental importance [11] [15]. Also, it can play an important role in extending the shelf life of cheese [15].

MTGase has been used to enhance the properties of rennet-coagulated cheese. However, sometimes the competitive interactions between MTGase and rennet during rennet coagulation may constitute an obstacle during cheese manufacture, depending on the step at which MTGase was added. Four methods have been suggested for adding MTGase during cheese making. The first method is to add the enzyme in cheese milk prior to adding the rennet. The second is to add MTGase simultaneously with rennet. The third is the addition of MTGase after a certain time of adding rennet. The last method is to add MTGase after curd cutting. The use of the first method prevented or considerably delayed milk coagulation [10] [17]. In this case, the enzymatic cross-linking impacted the primary [18] or the secondary stage of rennet coagulation [19] or both stages [20]. The simultaneous addition of MTGase and rennet significantly decreased the cheese hardness as well as increased the loss of proteins and fat in the whey [10] [15]. However, other studies recommended this method [21] [22]. The third method [17] [23] and the fourth one [10] [15] [16] have been recommended, as they positively influenced the composition, yield and sensory properties of produced cheese. Concerning camel-milk cheese, data are scarce for cheese made with MTGase [10]. This study recommended adding MTGase after curd cutting. However, there is no data available on the effect of MTGase on the properties of camel-milk soft cheese as a result of adding this enzyme to milk at a certain time after rennet addition.

On the other side, milk contains considerable amounts of antioxidants such as caseins, whey proteins, certain peptides, sulfur-rich amino acids, vitamins C, A and E, carotenoids, some minerals and enzyme systems [24]. Dairy products, particularly yogurt and cheese, have higher antioxidant properties as compared to the normal milk. Intake of these products reduced the risk of various types of cancer and other chronic diseases [25]. Additionally, the antioxidant activity of milk and its products is important for extending their shelf life [26]. Processing, packaging, storage conditions and other factors have an obvious influence on the proportions of antioxidants, which is directly relevant to oxidative stability of dairy products [25] [27]. Numerous researches respecting the impact of processing on the antioxidant activity of milk and dairy products have been conducted [28]. However, until now, rare studies have been carried out on the effect of MTGase on the antioxidant activity of dairy products [29] and there is no available data on this topic regarding camel milk products.

The aim of the present study was to investigate the effect of adding MTGase, with different concentrations, after renneting on the yield, texture, quality and antioxidant activity of soft cheese made from camel milk. MTGase was added to cheese milk at a concentration of 80,100 and $120 \mathrm{U} / \mathrm{L}$ after 20 and $30 \mathrm{~min}$ of 
rennet addition. The chemical composition, yield, hardness, DPPH radical scavenging activity, ferric ion reducing antioxidant power (FRAP) and sensory properties of fresh cheese were evaluated. Also, SDS-PAGE was performed to monitor the protein crosslinking by MTGase.

\section{Material and Methods}

\subsection{Materials}

Dromedary camel milk was collected from the herd of Camel Research Center, Marsa Matrouh, Egypt. Microbial Transglutaminase (MTGase, EC 2.3.2.13) of Streptoverticillium mobaraense, (ACTIVA ${ }^{\oplus} \mathrm{YG}$ ) with a specific activity of 100 U/g was obtained from Ajinomoto Europe Sales GmbH, Hamburg, Germany. Commercially available lyophilized culture (Express 0.1, DVS) and pure camel chymosin $\left(\right.$ Far- $\left.\mathrm{M}^{\otimes}\right)$ were supplied from Chr. Hansen Laboratories, Copenhagen, Denmark. 1, 1-diphenyl-2-picryl-hydrazyl (DPPH) was purchased from Sigma-Aldrich (Munich, Germany). Gallic acid, ferric chloride and potassium ferricyanide were obtained from Loba Chemie, Mumbai, India.

\subsection{Cheese Preparation}

Camel-milk soft cheese was prepared according to the method of [30] with some modifications. Camel milk ( $\mathrm{pH}, 6.58 \pm 0.01$; acidity, $0.16 \% \pm 0.01 \%$; total solids, $12.97 \% \pm 0.04 \%$; protein, $3.16 \% \pm 0.21 \%$ and fat, $3.95 \% \pm 0.07 \%)$ was heated to $65^{\circ} \mathrm{C}$ for 30 minutes, then the temperature of the milk was brought down to $40^{\circ} \mathrm{C}$. DVS starter culture $(0.2 \mathrm{~g} / \mathrm{L})$ was added and incubated for $30 \mathrm{~min}$, then $\mathrm{CaCl}_{2}(0.2 \mathrm{~g} / \mathrm{L})$ and camel chymosin $(0.6 \mathrm{~mL} / \mathrm{L})$ were added and gently mixed. MTGase in the range of 80,100 and $120 \mathrm{U} / \mathrm{L}$ of milk was added after 20 and 30 min of rennet addition. The cheese milk was left undisturbed to coagulate for approximately $3 \mathrm{~h}$. The whey drainage was performed by pouring the cheese curd into a plastic mold lined with a cheese cloth. After drainage of whey, the curd was pressed for $12 \mathrm{~h}$. The salt was distributed on cheese surface at a level of $3 \%$ of cheese curd. Cheese without MTGase was considered as control.

\subsection{Chemical Composition}

Milk and fresh cheese were analyzed for moisture, protein and fat (\%) using the AOAC procedures [31]. Titratable acidity (lactic acid \%) of milk was evaluated by titration with $0.1 \mathrm{~N} \mathrm{NaOH}$ in the presence of phenolphthalein as an indicator. The $\mathrm{pH}$ of milk was measured using a digital $\mathrm{pH}$ meter (Martini, Italy). All analyses were performed in triplicate.

\subsection{Yield Calculations}

The actual yield of cheese was determined as the quantity of cheese obtained from $100 \mathrm{Kg}$ of milk as the formula given by [32].

$$
\text { Actual yield }(\%)=\frac{\text { Cheese }(\mathrm{Kg})}{\operatorname{Milk}(\mathrm{Kg})} \times 100
$$


Moisture-adjusted cheese yield expressed as the quantity $(\mathrm{kg})$ of cheese produced with $60 \%$ moisture was calculated as follows:

$$
\text { Adjusted yield }(\%)=\frac{\text { Actual yield } \times(100-\text { Actual percentage of moisture })}{(100-\text { Desired percentage of moisture })}
$$

\subsection{Sodium Dodecyl Sulphate Polyacrylamide Gel Electrophoresis (SDS-PAGE)}

SDS-PAGE, $12.5 \% \mathrm{~T}$, was conducted under reducing conditions using the discontinuous buffer system described by [33]. SDS-PAGE was performed on cheese samples using a Mini-PROTEAN electrophoresis cell (Bio-Rad Laboratories, Hercules, CA, USA). One gram of each cheese sample was stirred with 15 $\mathrm{mL}$ of cold acetone for $10 \mathrm{~min}$ to get rid of the cheese fat and left to dry at room temperature. The dried powdered cheese $(20 \mathrm{mg})$ was mixed with $500 \mu \mathrm{L}$ of sample buffer. Samples were denatured by boiling for $5 \mathrm{~min}$, and then $7 \mu \mathrm{L}$ of each sample was injected. The data were analyzed by Total Lab software (V1.11).

\subsection{Hardness}

Cheese samples for texture analysis were obtained from the middle of the whole cheese block rather than from the surface to avoid surface effects. Cheese cubes $(20 \times 20 \times 20 \mathrm{~mm})$ were placed in plastic cups, sealed (to prevent dehydration) and tempered to $10^{\circ} \mathrm{C} \pm 0.5^{\circ} \mathrm{C}$ prior to analysis. Hardness was performed using the texture analyzer (Stable Micro Systems ltd. Vienna court, Lammas TA.XT. Plus) with cylindrical probe (30 mm diameter) and operated at a crosshead speed of $1 \mathrm{mms}^{-1}$ and compressed distance of $10 \mathrm{~mm}$. Hardness was evaluated in duplicate according to the procedure reported by [34].

\subsection{Determination of Antioxidant Activity}

\subsubsection{Preparation of Cheese Water-Soluble Extracts}

Water-soluble extracts (WSE) were prepared using the method described by [35]. Briefly, $10 \mathrm{~g}$ of cheese sample was suspended in $30 \mathrm{~mL}$ of distilled water and kept at $40^{\circ} \mathrm{C}$ for $1 \mathrm{~h}$ under gentle stirring. Then, the homogenates were centrifuged at $10,000 \times \mathrm{g}$ at $4^{\circ} \mathrm{C}$ for $30 \mathrm{~min}$. Thereafter, the top layer of fat was removed, the supernatant was filtered using Double Rings filter paper No. 102, and kept at $-20^{\circ} \mathrm{C}$ until analysis.

\subsubsection{DPPH Scavenging Activity}

Scavenging activity of the stable 1, 1-diphenyl-2-picrylhydrazyl (DPPH) radical was determined according to the procedure described by [36]. Two milliliters of $0.15 \mathrm{mM} \mathrm{DPPH}$, dissolved in methanol, were added to $1 \mathrm{~mL}$ of extracts, mixed well and left in the dark for $30 \mathrm{~min}$ at room temperature. Absorbance (A) was measured at $517 \mathrm{~nm}$ against distilled water as a blank using UV/Visible spectrophotometer, Pharmacia-LKB-Ultrospec III (Pharmacia, USA). The control was prepared by adding $2 \mathrm{~mL}$ of DPPH to $1 \mathrm{~mL}$ of methanol. The determination was carried out in triplicate. The results were expressed as a percentage of radical 
scavenging activity.

$$
\text { Radical scavenging activity }(\%)=\frac{\left(A_{\text {control }}-A_{\text {sample }}\right)}{A_{\text {control }}} \times 100
$$

\subsubsection{Ferric ion Reducing Antioxidant Power}

Ferric ion reducing antioxidant power (FRAP) was determined according to [37]. One milliliter of extracts was added to $2.5 \mathrm{~mL}$ of phosphate buffer $(0.1 \mathrm{M}$, $\mathrm{pH}$ 6.6) and $2.5 \mathrm{~mL}$ of potassium ferricyanide ( $1 \% \mathrm{w} / \mathrm{v})$. The mixture was then incubated in a water bath at $50^{\circ} \mathrm{C}$ for $20 \mathrm{~min}$ followed by cooling to room temperature and adding $2.5 \mathrm{~mL}$ of trichloroacetic acid $(10 \% \mathrm{w} / \mathrm{v})$. The contents of the tubes were centrifuged at $10,000 \times \mathrm{g}$ at $4^{\circ} \mathrm{C}$ for $10 \mathrm{~min}$. Next, $2.5 \mathrm{~mL}$ of supernatant was removed from each tube, and mixed with $2.5 \mathrm{~mL}$ of distilled water and $0.5 \mathrm{~mL}$ of ferric chloride solution $(0.1 \% \mathrm{w} / \mathrm{v})$. The mixtures were allowed to stand for $30 \mathrm{~min}$ then absorbance was measured at $700 \mathrm{~nm}$ using UV/Visible spectrophotometer, Pharmacia-LKB-Ultrospec III (Pharmacia, USA). The assay was done in triplicate. The FRAP values, expressed in mg gallic acid equivalents $(\mathrm{GAE}) / \mathrm{mL}$ extract, were derived from a standard curve.

\subsection{Sensory Evaluation}

Cheese samples were evaluated for organoleptic characteristics (color, flavor, taste, and texture), and overall acceptability. The evaluation was conducted by 10 panelists (6 males and 4 females) from the Department of Dairy Science and Technology, Faculty of Agriculture, Alexandria University, with ages ranging from 23 to 65 years; they have a good experience in the sensory evaluation of dairy products. Cheese samples $(20 \mathrm{~g})$ were presented in white plastic cups coded randomly with 3-digit numbers, at a temperature of $20^{\circ} \mathrm{C}$. Water was provided between evaluations of samples for mouth rinsing. The evaluation was identified using a 5-point hedonic scale (1 dislike extremely, 5 like extremely).

\subsection{Statistical Analysis}

Data were analyzed for statistical differences by a two-way analysis of variance (ANOVA) (first factor: MTGase concentration, second factor: time of addition). Means were compared by Duncan's test at the significance level of $P<0.05$. Statistical analyses were carried out using SAS, 2004 (SAS Institute, Inc., Cary, NC).

\section{Results and Discussion}

Adding MTGase during cheese manufacture is considered an important step for producing high-quality cheese with good coagulation properties [15] [17]. In the current study, MTGase was added to milk 20 and 30 min after rennet addition for two reasons. The first one is to give rennet an adequate time to cleave $\kappa$-casein because casein micelles are not able to aggregate until about $60 \%-80 \%$ of their $\kappa$-casein is degraded [38]. The second reason is to prevent the competitive interactions between MTGase and rennet during the primary stage of rennet 
coagulation due to the high susceptibility of $\kappa$-casein to MTGase. The insertion of $\kappa$-casein in the crosslinks induced by MTGase may prevent cleavage of $\kappa$-casein hence suppress the primary stage of coagulation [22].

\subsection{Chemical Composition}

The chemical composition (moisture, protein, fat, protein/dry matter (P/DM) and fat/dry matter (F/DM)) of camel-milk soft cheese with and without MTGase is presented in Table 1. The results of a two-way ANOVA test reveal that the moisture content of MTGase-treated cheese samples was significantly $(P<0.05)$ higher than that of control cheese (without MTGase). The cross-linking induced by MTGase increased the free volume inside the curd matrix and produced finer protein network, causing the curd to retain more water [39] [40]. Similar results have been obtained by [21] [41], who found a marked increase in the moisture content of white cheese treated with MTGase compared with the control.

Moreover, the MTGase concentration had an obvious influence on the cheese moisture content. Among MTGase-treated cheese, samples with $80 \mathrm{U}$ of MTGase had the lowest moisture content. Increasing MTGase concentration to $100 \mathrm{U}$ significantly $(P<0.05)$ increased the moisture content of cheese samples. While, the continuous increase of MTGase concentration up to $120 \mathrm{U}$ led to a slight, but significant, decrease in cheese moisture content. Gaspar and de Góes-Favoni [42] have reported that the appropriate concentration of MTGase is associated with an increase in water holding capacity. At this concentration, MTGase provides stable and highly porous gels, which able to retain water more efficiently. While increasing the concentration beyond the optimum level range of MTGase may cause a reduction in the water holding capacity due to reduced protein-water interactions and increased the number of inter- and intramolecular isopeptide bonds [42].

Table 1. Effect of MTGase concentration and time of addition on the chemical composition of camel-milk soft cheese (Two-way ANOVA).

\begin{tabular}{|c|c|c|c|c|c|}
\hline \multirow[b]{2}{*}{ Factors } & \multicolumn{5}{|c|}{ Parameters } \\
\hline & $\begin{array}{l}\text { Moisture } \\
(\%)\end{array}$ & Protein (\%) & Fat (\%) & P/DM (\%) & F/DM (\%) \\
\hline \multicolumn{6}{|c|}{$\begin{array}{c}\text { MTGase concentration } \\
\text { (U/L milk) }\end{array}$} \\
\hline Control & $58.3 \pm 0.84^{\mathrm{d}}$ & $15.3 \pm 0.25^{\mathrm{a}}$ & $21.0 \pm 0.60^{\mathrm{a}}$ & $36.8 \pm 0.56^{\mathrm{a}}$ & $50.4 \pm 0.04^{\mathrm{a}}$ \\
\hline 80 & $67.2 \pm 0.24^{c}$ & $11.3 \pm 0.48^{\mathrm{b}}$ & $16.3 \pm 0.50^{\mathrm{b}}$ & $34.4 \pm 1.23^{\mathrm{b}}$ & $49.6 \pm 1.36^{\mathrm{a}}$ \\
\hline 100 & $69.2 \pm 1.20^{\mathrm{a}}$ & $10.4 \pm 0.34^{\mathrm{c}}$ & $16.0 \pm 0.82^{\mathrm{b}}$ & $33.9 \pm 0.39^{\mathrm{b}}$ & $52.1 \pm 3.02^{\mathrm{a}}$ \\
\hline 120 & $68.7 \pm 1.09^{b}$ & $10.6 \pm 0.21^{c}$ & $15.3 \pm 0.50^{\mathrm{b}}$ & $33.9 \pm 0.61^{b}$ & $48.7 \pm 1.62^{\mathrm{a}}$ \\
\hline \multicolumn{6}{|c|}{ Time of addition (min) } \\
\hline 20 & $67.6 \pm 0.53^{\mathrm{B}}$ & $11.1 \pm 0.49^{\mathrm{A}}$ & $16.0 \pm 0.63^{\mathrm{A}}$ & $34.2 \pm 1.00^{\mathrm{A}}$ & $49.5 \pm 1.90^{\mathrm{A}}$ \\
\hline 30 & $69.1 \pm 1.32^{\mathrm{A}}$ & $10.5 \pm 0.33^{\mathrm{B}}$ & $15.7 \pm 0.82^{\mathrm{A}}$ & $33.9 \pm 0.54^{\mathrm{A}}$ & $50.7 \pm 2.95^{\mathrm{A}}$ \\
\hline
\end{tabular}


Also, the time of adding MTGase significantly $(P<0.05)$ affected the moisture content of cheese samples. As evident, the addition of MTGase to milk after 30 min of adding rennet increased the cheese moisture content compared to those samples to which the enzyme was added after 20 min of renneting. This may be attributed to the difference in the incubation time of milk with MTGase. In other words, cheese milk was left to coagulate in $180 \mathrm{~min}$. Thus, the addition of MTGase to milk after $30 \mathrm{~min}$ of renneting reduced the incubation time of milk with MTGase until the end of coagulation, i.e. $150 \mathrm{~min}$ versus $160 \mathrm{~min}$ when MTGase added after 20 min of renneting. Gharibzahedi et al. [14] have declared that MTGase concentration as well as the time and temperature of incubation are the main factors affecting the cheese moisture content.

In terms of protein content, the control cheese possessed the highest content of protein and $\mathrm{P} / \mathrm{DM}$, due to the decrease in its moisture content, compared to MTGase-treated samples. This finding agrees with those obtained by [21] [43] [44]. On the contrary, other studies showed that the use of MTGase increased the protein content in cheese samples to which the enzyme was added in comparison with control [10] [23]. Concerning treated cheeses, samples containing $80 \mathrm{U}$ of MTGase were the highest in their protein content $(P<0.05)$. Increasing the concentration of MTGase resulted in a significant decrease in the protein content. This is due to the high moisture content of these samples, as the decrease in the protein content was accompanied by a high percentage of moisture. However, there were no significant differences in protein content between samples containing 100 and $120 \mathrm{U}$ of MTGase. Moreover, the time of addition significantly $(P<0.05)$ impacted the protein content of cheeses at all MTGase concentrations. The protein content increased in the samples in which the enzyme was added after $20 \mathrm{~min}$ of renneting. The higher content of protein in these samples is likely due to the prolonged incubation period $(160 \mathrm{~min})$ of cheese milk with MTGase; thus an increase in the binding of protein was occurred, resulting in an increase in the protein content. The concentration of MTGase and the addition time had no impact on the P/DM content of cheese samples.

The results also show that the control cheese had the highest fat content, due to its lower moisture content, compared to MTGase-treated samples. However, there were no significant differences $(P>0.05)$ in $\mathrm{F} / \mathrm{DM}$ content between the control and MTGase-cheese samples. In addition, the concentration of MTGase and the time of addition had no effect on the fat and F/DM content of treated cheese samples.

\subsection{Cheese Yield}

The yield of camel-milk soft cheese as a result of adding MTGase is illustrated in Figure 1. The addition of MTGase at all concentrations to cheese milk after renneting significantly $(P<0.05)$ increased the cheese yield. MTGase free cheese possessed the lowest yield compared to other treated samples. Other studies observed the low yield of cheese from camel milk [4] [10]. The actual yields of all cheeses treated with MTGase were in the range of $19.0 \%-20.5 \%$, an increase of 


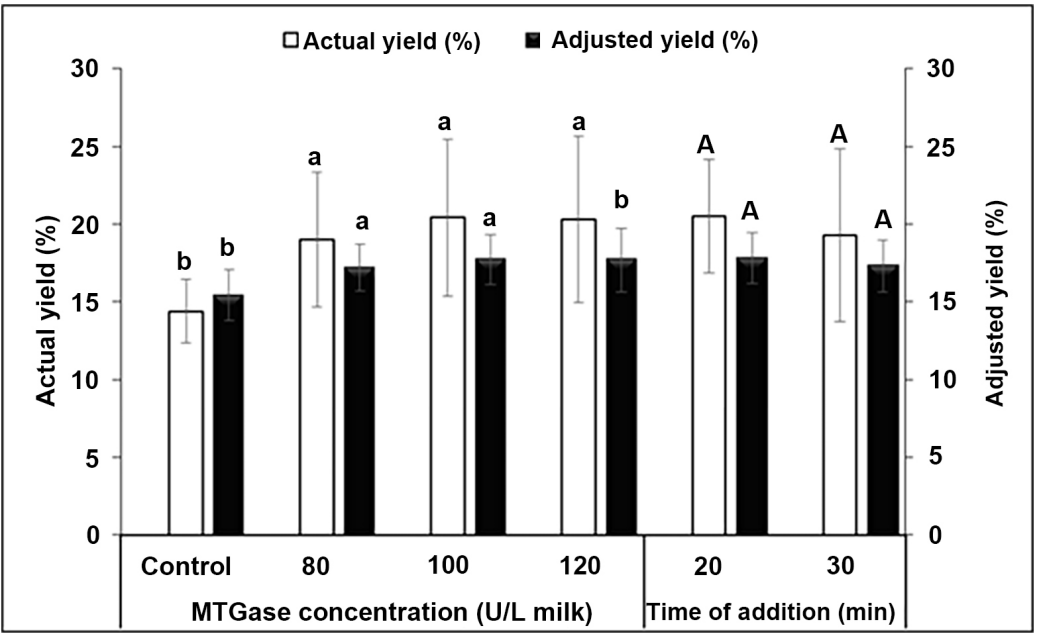

Figure 1. Effect of MTGase concentration and time of addition on the yield of camel-milk soft cheese (Two-way ANOVA). Mean values ( \pm standard deviation) with different small letters within the MTGase concentration are significantly different at $P<0.05$; means with different capital letters within the time of addition are significantly different at $P<0.05$.

$31.9 \%-42.4 \%$, respectively with respect to control. Similarly, the adjusted yield was increased by $11.7 \%, 14.9 \%$ and $14.9 \%$ when it added at a concentration of 80,100 and $120 \mathrm{U}$ compared to control. The increment in the yield of MTGase-cheeses mainly attributed to their high moisture content due to the addition of MTGase. These results are consistent with the previous studies by [15] [21] [43]. Ibrahim and Khalifa [10] found that adding $100 \mathrm{U}$ of MTGase/L milk after curd cutting significantly increased the yield value of camel-milk soft cheese, it was 15.13 versus $11.60 \%$ for control.

Increasing the concentration of MTGase from 80 to $120 \mathrm{U}$ did not improve the cheese yield. Besides, adding MTGase 20 or 30 min after renneting had the same impact on cheese yield. Other investigations have declared that the addition of MTGase increased the yield of cheeses in a concentration-dose manner [45]. However, [17] found that the addition of MTGase up to $60 \mathrm{U}$ to cow milk after renneting resulted in a noticeable increase in the cheese yield, followed by a slight decrease in the yield due to increased MTGase concentration over $60 \mathrm{U}$. In the present study, the increase in the moisture content of cheese treated with MTGase was accompanied by a decrease in protein content (Table 1); therefore the effect of enzyme concentration on increasing cheese yield was not significant. In conclusion, Adding MTGase after renneting significantly increased the yield of cheese. It is recommended to use MTGase at a concentration of $80 \mathrm{U}$ after 20 min of rennet addition to improve the yield of soft cheese made from camel milk.

\subsection{SDS-PAGE Electrophoresis}

SDS-PAGE is considered an acceptable method to monitor the action of MTGase due to it shows cross-linking caused by the enzyme through the forma- 
tion of new high molecular weight bands [46]. The impact of MTGase on the protein patterns of fresh soft cheese made from camel milk is illustrated in Figure 2. The electrophoretic patterns of cheese proteins showed the appearance of several bands on the gel, differed in their migration positions and band intensity. In all cheese samples, it is clear that casein was resolved into two major bands, $\alpha_{s^{-}}$and $\beta$-caseins, however, the intensity of these bands was higher in control than MTGase-treated samples. Further, there were new fractions of protein with different molecular weights appeared with samples containing MTGase. These new fractions were formed due to the action of MTGase, which catalyzes formation of chemical crosslinks within milk proteins, so formation of polymers with high molecular weight. These results agree with other studies, in which MTGase had the same effect on camel milk proteins [39]. The decrease in the intensity of caseins bands on the gel elucidated that these proteins are preferred substrate for MTGase due to their flexible open structure [47] and due to the absence of disulphide bonds in $\alpha_{s 1}$-and $\beta$-caseins, leaving the reactive groups exposed to the enzyme [48].

Regarding whey proteins, the changes in the intensity of the whey proteins bands were not sufficiently clear as caseins. This mostly attributed to the low-temperature heat treatment used in current study; cheese milk was pasteurized at $65^{\circ} \mathrm{C} / 30 \mathrm{~min}$. This thermal treatment is insufficient to improve the reactivity of whey proteins towards MTGase. At this temperature, studies showed that no effect was found on the whey proteins of camel milk [49] [50]. The denaturation of whey proteins is necessary for MTGase to work effectively. The existence of whey proteins, particularly $\alpha$-lactalbumin, in their globular shape impedes the action of the enzyme. Gauche [51] reported that native whey proteins are poor substrates for TGase, denaturation process leads to exposure of more sites for TGase-specific reaction. Recently, [39] declared that thermal treatment of camel milk before reaction with MTGase $\left(90^{\circ} \mathrm{C} / 15 \mathrm{~min}\right)$ significantly enhanced the reactivity of whey proteins towards protein cross-linking due to a series of interactions arising from heating.

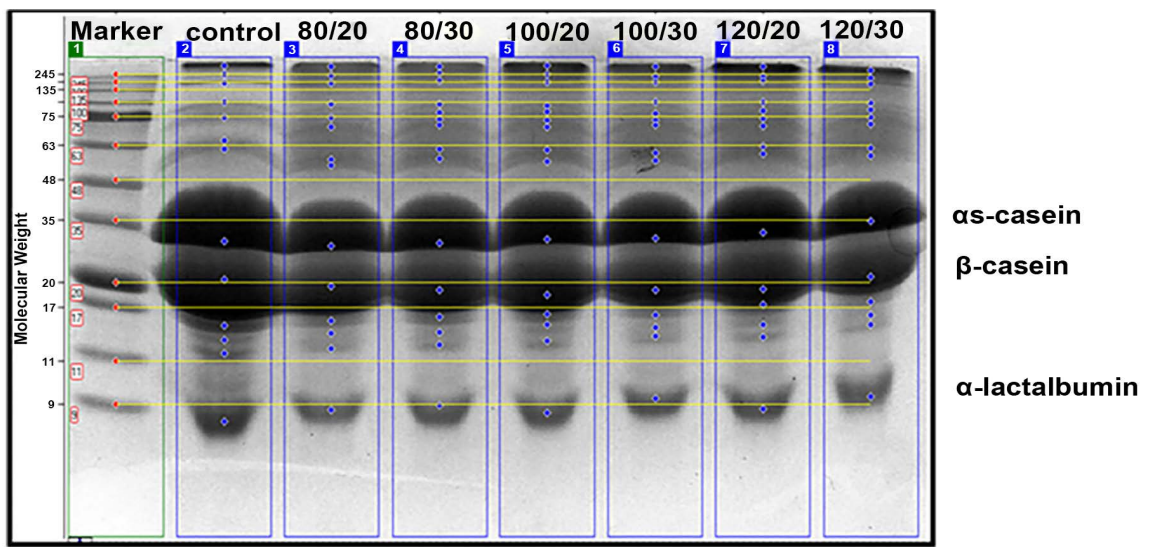

Figure 2. SDS-PAGE $(12.5 \% \mathrm{~T})$ of camel-milk soft cheese treated with MTGase at different concentration (80,100 and $120 \mathrm{U} / \mathrm{L}$ of milk) and addition time (20 and $30 \mathrm{~min}$ after renneting). 
The effect of MTGase concentration on the milk proteins is almost the same except for the treatment that contains $80 \mathrm{U}$ of the enzyme. In addition, the density of new polymers with high molecular weight decreased by increasing the time of addition at all MTGase concentration. This behavior is due to the long incubation time of milk with MTGase when it added 20 min after renneting. Overall, the electrophoretic pattern of the sample with $80 \mathrm{U}$ of MTGase and addition time of 20 min was somewhat differed from that of other treated samples as the new bands were more intense as evidenced by Total Lab software.

\subsection{Hardness}

Hardness is the force required for compressing a cheese between the molars [52]. The results in Figure 3 clearly show that the hardness was significantly $(P<$ $0.05)$ increased in all cheeses that made using milk treated with MTGase when compared to control. This is due to the fact that MTGase could modify the textural properties of cheese through the formation of covalent bonds of $\varepsilon$-( $\gamma$-glutamyl) lysine, which were catalyzed by the enzyme [15] [41] [45]. The intra- and intermolecular crosslinks induced by this enzyme yielded a strong three-dimensional gel network thus increased the hardness of cheeses containing MTGase [53].

Regarding the MTGase-treated samples, it can be observed that the hardness was the highest $(P<0.05)$ in the sample made using $80 \mathrm{U}$ of the enzyme. There was a significant reduction in hardness with increasing the dosage of MTGase more than $80 \mathrm{U}$. Moreover, there were no significant differences in hardness between the samples with 100 and $120 \mathrm{U}$ of MTGase. Similar results have also been obtained with paneer, as further increase in the concentration of MTGase

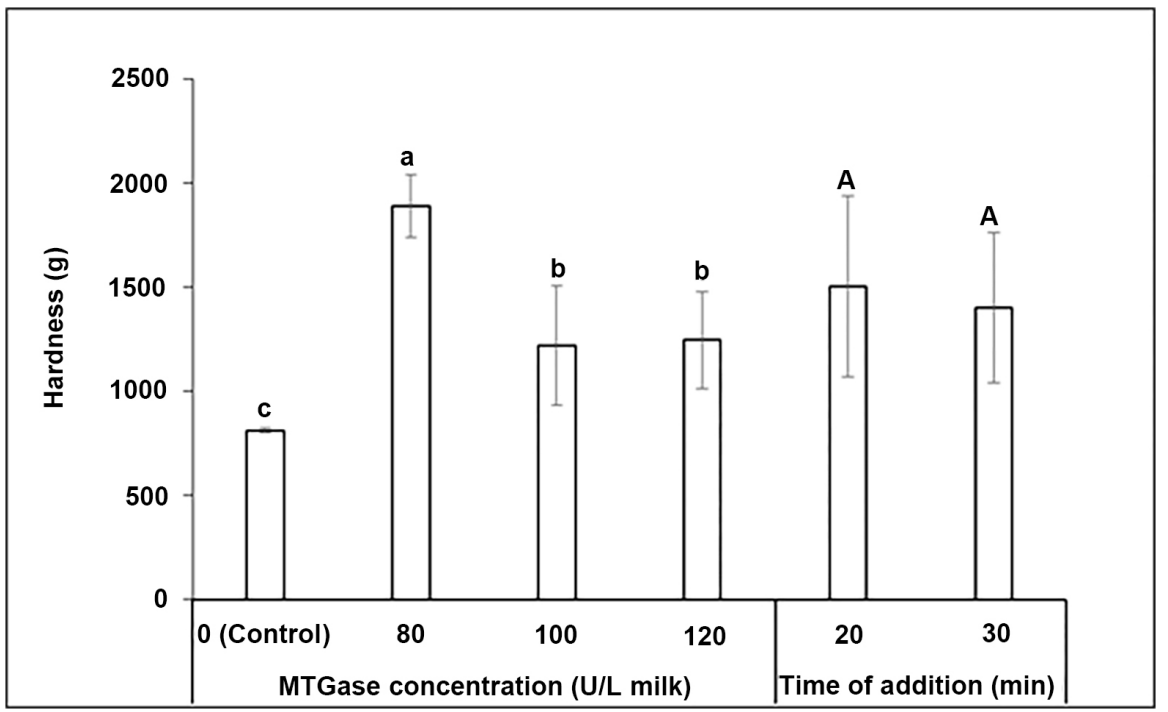

Figure 3. Effect of MTGase concentration and time of addition on the hardness of camel-milk soft cheese (Two-way ANOVA). Mean values ( \pm standard deviation) with different small letters within the MTGase concentration are significantly different at $P<$ 0.05 ; means with different capital letters within the time of addition are significantly different at $P<0.05$. 
significantly $(P<0.05)$ decreased the hardness of the samples [45]. Likewise, [15] found that adding MTGase after curd cutting from 12 up to $60 \mathrm{U} / \mathrm{L}$ milk significantly increased the hardness value of cow-milk soft cheese, increasing the enzyme concentration to $72 \mathrm{U} / \mathrm{L}$ led to a remarkable drop in hardness. A study by [10] found that adding MTGase (0 - $100 \mathrm{U} / \mathrm{L}$ milk) after curd cutting caused an improvement in the hardness of camel-milk soft cheese that increased with MTGase concentration, the maximum hardness was recorded in cheese contained $100 \mathrm{U}$ of the enzyme.

The higher protein content of cheese containing $80 \mathrm{U}$ of MTGase, together with the action of the enzyme, could be the reason for the harder texture of this cheese in comparison with other treated samples. Earlier, [54] reported that proteins play a significant role in cheese texture since they represent the only continuous solid phase of the product. Hence, any modification of the nature or the amount of the protein will alter the texture of cheese. Whereas, the cause of low hardness in samples with 100 and $120 \mathrm{U}$ of MTGase could be returned to the higher moisture content of these samples. The water content of the product is a determining factor for texture; therefore, small variations in the water content will highly impact the firmness [54]. Lately, [21] have reported that increased the serum pores number in the microstructure of MTGase-treated cheese resulted in lowering of the hardness with respect to the control cheese due to the plasticizer role of water, which give the cheese structure more flexibility.

With regard to the addition time of MTGase, the results show that adding the enzyme either 20 or $30 \mathrm{~min}$ after adding rennet had no significant impact on the hardness of camel milk soft cheese.

\subsection{Antioxidant Activity}

Antioxidant capacity assays are beneficial to determine the overall antioxidant activity in foods [25]. In the current study, the antioxidant activity of cheese water-soluble extracts was measured by two different assays, which are DPPH radical scavenging activity and FRAP. These assays were used to evaluate the antioxidant activity from amino acids in milk and dairy products that can act as hydrogen donors [25].

The influence of MTGase on the antioxidant activity of fresh soft cheese is illustrated in Figure 4. As shown, the water extract of control samples exhibited the highest DPPH radical scavenging activity and FRAP value $(P<0.05)$ compared to MTGase-treated samples. As expected, the antioxidant activity of cheese decreased by adding MTGase. Cheese possesses antioxidant capacity because it contains antioxidants, primarily casein. However, cheeses show variation of this activity due to many factors of which, the processing conditions as well as the difference in their composition and structure [26]. MTGase as a transferase forms new inter- and intramolecular $\mathcal{\varepsilon}$ - $(\gamma$-glutamyl) lysine bonds by cross-linking lysine and glutamine residues [11], result in the polymerization of almost milk proteins and peptides [39]. The polymerization process could 


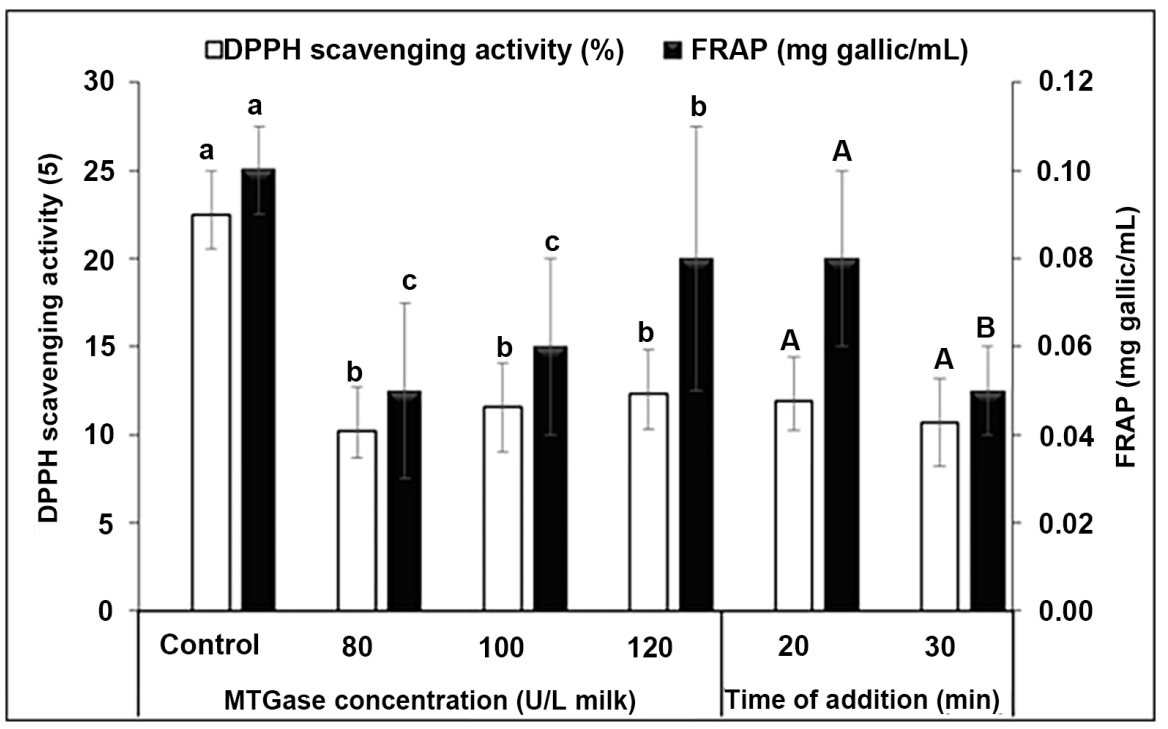

Figure 4. Effect of MTGase concentration and time of addition on the antioxidant activity of camel-milk soft cheese (Two-way ANOVA). Mean values ( \pm standard deviation) with different small letters within the MTGase concentration are significantly different at $P<0.05$; means with different capital letters within the time of addition are significantly different at $P<0.05$.

decrease the antioxidant activity of the final product via inserting specific amino acid residues with antioxidant properties such as lysine in the interaction. It has been reported that the amino acid profile determines the antioxidant activity of proteins [25]. Also, the reduction in the antioxidant activity of MTGase-treated cheese may be due to the nature of the curd microstructure. The additional cross-linking induced by MTGase produces a dense protein network [39]. Recently, [55] have mentioned that the microstructure of the curd can influence its antioxidant properties, as the densest network showed the lowest antioxidant capacity due to the presence of protein segments not flexible enough to act as antioxidants. Beyond that, the decrease in protein content may be another reason for the decrease in antioxidant activity of MTGase-treated cheese in comparison to control.

In addition, the DPPH scavenging activity of treated cheese was not affected by the increased concentration of MTGase. Similarly, Increasing the MTGase concentrations from 80 to $100 \mathrm{U}$ did not affect the FRAP value. However, increasing the enzyme dose above $100 \mathrm{U}$ resulted in a slight, but significant, increase in the value of FRAP. Moreover, no significant differences $(P>0.05)$ were found between the treated cheeses in terms of DPPH scavenging activity due to the time of addition. On the contrary, the time of addition significantly $(P<$ 0.05) affected the FRAP values. The FRAP value for samples to which MTGase was added 20 minutes after rennet addition was higher $(P<0.05)$ than those for which the enzyme was added after 30 minutes. There is no explanation for this behavior; it is assumed that adding MTGase $20 \mathrm{~min}$ after rennet addition provides a longer incubation time for MTGase with milk that may reduce or even 
not affect the antioxidant activity of the final product as in DPPH scavenging activity.

\subsection{Sensory Evaluation}

The sensory evaluation of the control and MTGase-treated cheese samples was carried out for color, flavor, taste, texture and overall acceptability (Table 2). The results revealed that no significant $(P>0.05)$ differences were found between the untreated and MTGase-treated cheese samples in terms of color, flavor and taste. Similar data for soft cheese were reported regarding the color [15] [43] and the flavor [15]. Except that [43] found that MTGase has a positive effect on the cheese flavor. Concerning taste, it is worth mentioning that despite there were no statistical differences between the control and treated samples in the taste scores, the panelists were able to discern a creamy taste in the MTGase-treated cheese which was not found in control. Other investigations have confirmed this finding [15] [43].

With regard to texture, the control recorded the lowest rating for texture in comparison with MTGase-treated samples. This result confirms the previous results concerning the positive influence of this enzyme on the texture of soft cheese [43] [56]. The enhancement of texture in treated cheese could be due to its high water content and the cross-linking bonds between protein molecules, which caused by the enzyme as reported by [44] [56]. On the otherwise, [15] found that the texture of soft cheese was not significantly impacted by the addition of MTGase. The results of sensory evaluation also reflected that MTGase concentration did not impact the texture of cheese samples.

Also, results revealed that MTGase-treated samples had higher rating compared with control for overall acceptability, particularly those samples containing

Table 2. Effect of MTGase concentration and time of addition on the sensory properties of camel-milk soft cheese (Two-way ANOVA).

\begin{tabular}{|c|c|c|c|c|c|}
\hline \multirow[b]{2}{*}{ Factors } & \multicolumn{5}{|c|}{ Parameters } \\
\hline & $\begin{array}{l}\text { Color } \\
(5)\end{array}$ & $\begin{array}{c}\text { Flavor } \\
(5)\end{array}$ & $\begin{array}{l}\text { Taste } \\
(5)\end{array}$ & $\begin{array}{l}\text { Texture } \\
\text { (5) }\end{array}$ & $\begin{array}{c}\text { Overall acceptability } \\
\text { (5) }\end{array}$ \\
\hline \multicolumn{6}{|c|}{$\begin{array}{c}\text { MTGase concentration } \\
(\mathrm{U} / \mathrm{L} \text { milk) }\end{array}$} \\
\hline Control & $4.3 \pm 0.82^{\mathrm{a}}$ & $3.9 \pm 1.07^{\mathrm{a}}$ & $3.6 \pm 1.11^{\mathrm{a}}$ & $2.9 \pm 1.24^{\mathrm{b}}$ & $3.2 \pm 0.91^{\mathrm{b}}$ \\
\hline 80 & $4.6 \pm 0.63^{\mathrm{a}}$ & $4.0 \pm 1.11^{\mathrm{a}}$ & $4.0 \pm 1.01^{\mathrm{a}}$ & $3.8 \pm 0.85^{\mathrm{a}}$ & $3.8 \pm 0.72^{\mathrm{ab}}$ \\
\hline 100 & $4.7 \pm 0.47^{\mathrm{a}}$ & $4.3 \pm 0.91^{\mathrm{a}}$ & $4.3 \pm 1.09^{\mathrm{a}}$ & $3.6 \pm 0.72^{\mathrm{a}}$ & $3.6 \pm 0.72^{\mathrm{ab}}$ \\
\hline 120 & $4.6 \pm 0.50^{\mathrm{a}}$ & $4.2 \pm 0.97^{\mathrm{a}}$ & $4.2 \pm 0.99^{\mathrm{a}}$ & $4.0 \pm 0.57^{\mathrm{a}}$ & $4.1 \pm 0.63^{\mathrm{a}}$ \\
\hline \multicolumn{6}{|c|}{ Time of addition ( $\mathrm{min}$ ) } \\
\hline 20 & $4.7 \pm 0.48^{\mathrm{A}}$ & $4.2 \pm 0.89^{A}$ & $4.2 \pm 0.90^{\mathrm{A}}$ & $4.0 \pm 0.58^{A}$ & $4.0 \pm 0.66^{\mathrm{A}}$ \\
\hline 30 & $4.6 \pm 0.58^{\mathrm{A}}$ & $4.1 \pm 1.09^{\mathrm{A}}$ & $4.1 \pm 1.12^{\mathrm{A}}$ & $3.6 \pm 0.82^{\mathrm{A}}$ & $3.8 \pm 0.75^{\mathrm{A}}$ \\
\hline
\end{tabular}

Mean values ( \pm standard deviation) with different small letters within the MTGase concentration are significantly different at $P<0.05$; means with different capital letters within the time of addition are significantly different at $P<0.05$. 
$120 \mathrm{U}$ of MTGase. No significant $(P>0.05)$ differences were found among MTGase-treated samples as a result of increasing the dose of the enzyme. Moreover, the addition of MTGase 20 or $30 \mathrm{~min}$ after adding rennet had the same impact on the sensory characteristics of all cheese samples. In sum, inclusion of MTGase enhanced the texture and overall acceptability of fresh soft cheese made from camel milk.

\section{Conclusion}

The cross-linking between camel-milk proteins caused by MTGase enhanced the properties of soft cheese but negatively influenced its antioxidant activity. Moreover, the concentration of MTGase and time of addition highly impacted some properties of cheese. Despite the increase in the yield of MTGase cheese was mainly related to the high moisture content, this increase in moisture did not negatively affect the properties of cheese; the treated cheese was superior in its texture and overall acceptability compared to control. MTGase added to milk at a concentration of $80 \mathrm{U}$ after $20 \mathrm{~min}$ of renneting is recommended for improving the yield, textural and some sensory properties of soft cheese made from camel milk.

\section{Acknowledgements}

The authors would like to thank Prof. Dr. Hassan Zaky, Animal and Poultry Production Division, Desert Research Centre, for his assistance with the statistical analysis.

\section{Conflicts of Interest}

The authors declare no conflicts of interest regarding the publication of this paper.

\section{References}

[1] Yadav, A.K., Kumar, R., Priyadarshini, L. and Singh, J. (2015) Composition and Medicinal Properties of Camel Milk: A Review. Asian Journal of Dairy and Food Research, 34, 83-91. https://doi.org/10.5958/0976-0563.2015.00018.4

[2] Farah, Z. and Rüegg, M.W. (1989) The Size Distribution of Casein Micelles in Camel Milk. Food Microstructure, 8, 211-216.

[3] Bornaz, S., Sahli, A., Attalah, A. and Attia, H. (2009) Physicochemical Characteristics and Renneting Properties of Camels' Milk: A Comparison with Goats', Ewes' and Cows' Milks. International Journal of Dairy Technology, 62, 505-513. https://doi.org/10.1111/j.1471-0307.2009.00535.x

[4] Derar, A.M.A. and El Zubeir, I.E.M. (2016) Effect of Fortifying Camel Milk with Sheep Milk on the Processing Properties, Chemical Composition and Acceptability of Cheeses. Journal of Food Science and Engineering, 6, 215-226. https://doi.org/10.17265/2159-5828/2016.04.004

[5] El-Zeini, H.M. (2006) Microstructure, Rheological and Geometrical of Fat globules of Milk from Different Animal Species. Polish Journal of Food and Nutrition Science, 15, 147-154. 
[6] Kappeler, S. (1998) Compositional and Structural Analysis of Camel Milk Proteins with Emphasis on Protective Proteins. Swiss Federal Institute of Technology, ETH, Zurich, Switzerland.

[7] Mehaia, M.A. (2006) Manufacture of Fresh Soft White Cheese (Domiati-Type) from Dromedary Camels' Milk Using Ultrafiltration Process. Journal of Food Technology, 4, 206-212.

[8] Boudjenah-Haroun, S.L., Laleye, S., Chahra, L.C.S., Farida, M., Saliha, S.A. and Abderrahmane, M. (2012) Coagulation of Camel Milk Using Dromedary Gastric Enzymes as a Substitute of the Commercial Rennet. American Journal of Food Technology, 7, 409-419. https://doi.org/10.3923/ajft.2012.409.419

[9] Walle, T., Kurtu, M.Y., Ipsen, R., Hailu, Y. and Eshetu, M. (2017) Coagulation and Preparation of Soft Unripened Cheese from Camel Milk Using Camel Chymosin. East African Journal of Sciences, 11, 99-106.

[10] Ibrahim, A.H. and Khalifa, S.A. (2013) Influence of Protein Cross-Linking Enzymes of Soft Cheese Properties Made from Camel's Milk. Zagazig Journal of Agricultural Research, 40, 1133-1140.

[11] Motoki, M. and Seguro, K. (1998) Transglutaminase and Its Use for Food Processing. Trends in Food Science \& Technology, 9, 204-210. https://doi.org/10.1016/S0924-2244(98)00038-7

[12] Romeih, E. and Walker, G. (2017) Recent Advances on Microbial Transglutaminase and Dairy Application. Trends in Food Science \& Technology, 62, 133-140. https://doi.org/10.1016/j.tifs.2017.02.015

[13] Moschopoulou, E. (2018) Microbial Non-Coagulant Enzymes Used in Cheese Making. In: Öztürkoğlu Budak, Ş. and Akal, H.C., Eds., Microbial Cultures and Enzymes in Dairy Technology, IGI Global, Hershey, PA, 204-221. https://doi.org/10.4018/978-1-5225-5363-2.ch011

[14] Gharibzahedi, S.M.T., Koubaa, M., Barba, F.J., Greiner, R., George, S. and Roohinejad S (2018) Recent Advances in the Application of Microbial Transglutaminase Cross Linking in Cheese and Ice Cream Products: A Review. International Journal of Biological Macromolecules, 107, 2364-2374. https://doi.org/10.1016/j.ijbiomac.2017.10.115

[15] Mahmood, W.A. and Sebo, N.H. (2009) Effect of Microbial Transglutaminase Treatment on Soft Cheese Properties. Mesopotamia Journal of Agriculture, 37, 1-9. https://doi.org/10.33899/magrj.2009.27525

[16] Cozzolino, A., Di Pierro, P., Mariniello, L., Sorrentino, A., Masi, P. and Porta, R. (2003) Incorporation of Whey Proteins into Cheese Curd by Using Transglutaminase. Biotechnology and Applied Biochemistry, 38, 289-295. https://doi.org/10.1042/BA20030102

[17] Othman, E.K., Gomaa, M.A.E., Ayad, E.H.E., Awad, S.A. and Darwish, S.M. (2015) Effect of Renneting Time on the Yield and Characteristics of Low Fat Soft Cheese as Affected by Transglutaminase. 12th Egyptian Conference of Dairy Science and Technology, Cairo, 9-11.

[18] O’Sullivan, M.M., Kelly, A.L. and Fox, P.F. (2002) Influence of Transglutaminase Treatment on Some Physico-Chemical Properties of Milk. Journal of Dairy Research, 69, 433-442. https://doi.org/10.1017/S0022029902005617

[19] Huppertz, T. and de Kruif, C.G. (2007) Rennet-Induced Coagulation of Enzymatically Cross-Linked Casein Micelles. International Dairy Journal, 17, 442-447. https://doi.org/10.1016/j.idairyj.2006.06.026

[20] Bönisch, M.P., Heidebach, T.C. and Kulozik, U. (2008) Influence of Transglutami- 
nase Protein Cross-Linking on the Rennet Coagulation of Casein. Food Hydrocolloids, 22, 288-297. https://doi.org/10.1016/j.foodhyd.2006.11.015

[21] Sayadi, A., Madadlou, A. and Khosrowshahi, A. (2013) Enzymatic Cross-Linking of Whey Proteins in Low Fat Iranian White Cheese. International Dairy Journal, 29, 88-92. https://doi.org/10.1016/j.idairyj.2012.10.006

[22] Domagała, J., Najgebauer-Lejko, D., Wieteska-Śliwa, I., Sady, M., Wszołek, M., Bonczar, G. and Filipczak-Fiutak, M. (2016) Influence of Milk Protein Cross-Linking by Transglutaminase on the Rennet Coagulation Time and the Gel Properties. Journal of the Science of Food and Agriculture, 96, 3500-3507.

https://doi.org/10.1002/jsfa.7534

[23] De Sá, E.M.F and Bordignon-Luiz, M.T. (2010) The Effect of Transglutaminase on the Properties of Milk Gels and Processed Cheese. International Journal of Dairy Technology, 63, 243-251. https://doi.org/10.1111/j.1471-0307.2010.00568.x

[24] Grażyna, C., Hanna, C., Adam, A. and Magdalena, B.M. (2017) Natural Antioxidants in Milk and Dairy Products. International Journal of Dairy Technology, 70, 165-178. https://doi.org/10.1111/1471-0307.12359

[25] Khan, I.T., Nadeem, M., Imran, M., Ullah, R., Ajmal, M. and Jaspal, M.H. (2019) Antioxidant Properties of Milk and Dairy Products: A Comprehensive Review of the Current Knowledge. Lipids in Health and Disease, 18, 41.

https://doi.org/10.1186/s12944-019-0969-8

[26] Fardet, A. and Rock, E. (2018) In Vitro and in Vivo Antioxidant Potential of Milks, Yoghurts, Fermented Milks and Cheeses: A Narrative Review of Evidence. Nutrition Research Reviews, 31, 52-70. https://doi.org/10.1017/S0954422417000191

[27] Bonilla, J. and Sobral, P.J.A. (2019) Gelatin-Chitosan Edible Film Activated with Boldo Extract for Improving Microbiological and Antioxidant Stability of Sliced Prato Cheese. International Journal of Food Science and Technology, 54, 1617-1624. https://doi.org/10.1111/ijfs.14032

[28] Gholamhosseinpour, A. and Hashemi, S.M.B. (2019) Ultrasound Pretreatment of Fermented Milk Containing Probiotic Lactobacillus plantarum AF1: Carbohydrate Metabolism and Antioxidant Activity. Journal of Food Process Engineering, 42, e12930. https://doi.org/10.1111/jfpe.12930

[29] Yuan, H., Lv, J., Gong, J., Xiao, H., Zhao, G., Xiao, G., Xu, H. and Wang, W. (2018) Microbial Transglutaminase Enhances Antioxidant Activity of Yogurt Through Altering Pattern of Water-Soluble Peptides and Increasing Release of Amino Acids. International Journal of Food Science \& Technology, 53, 1030-1044. https://doi.org/10.1111/ijfs.13679

[30] Fahmi, A.H. and Sharara H.A. (1950) Studies on Egyptian Domiati Cheese. Journal of Dairy Research, 17, 312-328. https://doi.org/10.1017/S0022029900005860

[31] AOAC (2005) Official Methods of Analysis of the Association Analytical Chemists, 18th Edition, Association of Official Analytical Chemistry, Gaithersburg, MD.

[32] Fox, P.F., Guinee T.P., Cogan, T.M. and Mc Sweeney P.L. (2000) Fundamentals of Cheese Science. Aspen Publishers Inc., Gaithersburg, MD.

[33] Laemmli, U.K. (1970) Cleavage of Structural Proteins during the Assembly of the Head of Bacteriophage T4. Nature, 277, 680-685.

https://doi.org/10.1038/227680a0

[34] Wium, H., Gross, M. and Qvist, K.B. (1997) Uniaxial Compression of UF-Feta Cheese Related to Sensory Texture Analysis. Journal of Texture Studies, 28, 455-476. https://doi.org/10.1111/j.1745-4603.1997.tb00128.x 
[35] Kariyawasam, K.M.G.M.M., Jeewanthi, R.K.C., Lee, N-K. and Paik, H-D. (2019) Characterization of Cottage Cheese Using Weissella cibaria D30: Physicochemical, Antioxidant, and Antilisterial Properties. Journal of Dairy Science, 102: 3887-3893. https://doi.org/10.3168/jds.2018-15360

[36] Lim, Y.Y. and Quah, E.P.L. (2007) Antioxidant Properties of Different Cultivars of Portulaca oleracea. Food Chemistry, 103, 734-740. https://doi.org/10.1016/j.foodchem.2006.09.025

[37] Oyaizu, M. (1986) Studies on Products of Browning Reaction: Antioxidative Activities of Products of Browning Reaction Prepared from Glucosamine. Japan Journal of Nutrition, 44, 307-315. https://doi.org/10.5264/eiyogakuzashi.44.307

[38] Dalgleish, D.G. (1992) The Enzymatic Coagulation of Milk. In: Fox, P.F., Ed., Advanced Dairy Chemistry-1: Proteins, Elsevier Applied Science Publication, London, 579-619.

[39] Abou-Soliman, N.H.I., Sakr, S.S. and Awad, S. (2017) Physico-Chemical Microstructural and Rheological Properties of Camel-Milk Yogurt as Enhanced by Microbial Transglutaminase. Journal of Food Science and Technology, 54, 1616-1627. https://doi.org/10.1007/s13197-017-2593-9

[40] Farnsworth, J.P., Li, J., Hendricks, G.M. and Guo, M.R. (2006) Effects of Transglutaminase Treatment on Functional Properties and Probiotic Culture Survivability of Goat Milk Yogurt. Small Ruminant Research, 65, 113-121. https://doi.org/10.1016/j.smallrumres.2005.05.036

[41] Özer, B., Hayaloglu, A.A., Yaman, H., Gürsoy, A. and Şener, L. (2013) Simultaneous Use of Transglutaminase and Rennet in White-Brined Cheese Production. International Dairy Journal, 33, 129-134. https://doi.org/10.1016/j.idairyj.2013.02.001

[42] Gaspar, A.L.C. and de Góes-Favoni S.P. (2015) Action of Microbial Transglutaminase (MTGase) in the Modification of Food Proteins: A Review. Food Chemistry, 171, 315-322. https://doi.org/10.1016/j.foodchem.2014.09.019

[43] Karzan, T.M., Nawal, H.S. and Ashna, T.A. (2016) The Effect of Microbial Transglutaminase Enzyme on Some Physicochemical and Sensory Properties of Goat's Whey Cheese. International Food Research Journal, 23, 688-693.

[44] Ibrahim, O.A., Nour, M.M., Khorshid, M.A., El-Hofi, M.A., El-Tanboly, E.E. and Abd-Rabou, N.S. (2017) UF-White Soft Cheese Cross-Linked by Rosemary Transglutaminase. International Journal of Dairy Science, 12, 64-72. https://doi.org/10.3923/ijds.2017.64.72

[45] Prakasan, V., Chawla, S.P. and Sharma, A. (2015) Effect of Transglutaminase Treatment on Functional Properties of Paneer. International Journal of Current Microbiology and Applied Sciences, 4, 227-238.

[46] Pinterits, A. and Arntfield S.D. (2008) Improvement of Canola Protein Gelation Properties through Enzymatic Modification with Transglutaminase. LWT-Food Science and Technology, 41, 128-138. https://doi.org/10.1016/j.lwt.2007.01.011

[47] Monogioudi, E., Creusot, N., Kruus, K., Gruppen, H., Buchert, J. and Mattinen, M. (2009) Cross-Linking of $\beta$-Casein by Trichoderma reesei Tyrosinase and Streptoverticillium mobaraense Transglutaminase Followed by SEC-MALLS. Food Hydrocolloids, 23, 2008-2015. https://doi.org/10.1016/j.foodhyd.2009.03.011

[48] Özrenk, E. (2006) The Use of Transglutaminase in Dairy Products. International Journal of Dairy Technology, 59, 1-7. https://doi.org/10.1111/j.1471-0307.2006.00220.x

[49] Farah, Z. (1986) Effect of Heat Treatment on Whey Proteins of Camel Milk. Milchwissenschaft, 41, 763-765. 
[50] Elagamy, E.I. (2000) Effect of Heat Treatment on Camel Milk Proteins with Respect to Antimicrobial Factors: A Comparison with Cows' and Buffalo Milk Proteins. Food Chemistry, 68, 227-232. https://doi.org/10.1016/S0308-8146(99)00199-5

[51] Gauche, C., Vieira, J.T.C., Ogliari, P.J. and Bordignon-Luiz, M.T. (2008) Crosslinking of Milk with Whey Proteins by Transglutaminase. Process Biochemistry, 43, 788-794. https://doi.org/10.1016/j.procbio.2008.04.004

[52] Awad, S. (2011) Texture and Microstructure. In: Cruz, R.M.S., Ed., Practical Food and Research, Nova Science publishers, Inc., New York, 361-391.

[53] Lim, T., Easa, A., Karim, A., Bhat, R. and Liong, M. (2011) Development of Soy-Based Cream Cheese via the Addition of Microbial Transglutaminase, Soy Protein Isolate and Maltodextrin. British Food Journal, 113, 1147-1172. https://doi.org/10.1108/00070701111174587

[54] Adda, J., Gripon, J.C. and Vassal, L. (1982) The Chemistry of Flavour and Texture Generation in Cheese. Food Chemistry, 9, 115-129. https://doi.org/10.1016/0308-8146(82)90073-5

[55] Pattorn, S. and Hongsprabhas, P. (2013) Effect of Coagulants on Antioxidant Capacity of Milk Protein Curds and Their Tryptic Hydrolysates. Journal of Food Biochemistry, 37, 203-211. https://doi.org/10.1111/j.1745-4514.2011.00625.x

[56] Ahmed, M.A., El-Nimer, A.M.M., Mostafa M.A. and Omar, H. (2015) Effect of Fat Replacer or Transglutaminase on the Quality of Low-Fat Gouda-Like Cheese. World Journal of Dairy \& Food Sciences, 10, 170-180. 